\title{
RESEARCH ON WATER QUALITY USED IN THE MILK INDUSTRY IN SIBIU COUNTY (TRANSYLVANIA, ROMANIA)
}

Mihaela TIȚA *, Adrian DABIJA **, Ovidiu TIȚA * and Daniela NAIARETTI ***

* "Lucian Blaga" University of Sibiu, Department of Agricultural Sciences and Food Engineering, Dr. Ion Raţiu Street 7-9, Sibiu, Sibiu County, Romania, RO-550012, tita_mihaeladriana@yahoo.com, ovidiu.tita@ulbsibiu.ro

** University of Suceava, Department of Food Technology, Food Safety Production and Environment, University Street 13, Suceava, Suceava County, Romania, RO-720229, adriana.dabija@fia.usv.ro

*** "Lucian Blaga” University of Sibiu, Department of Agricultural Sciences and Food Engineering, Dr. Ion Raţiu Street 7-9, Sibiu, Romania, Medicine Research Center, daria2005daria@yahoo.com

DOI: 10.1515/trser-2015-0022

KEYWORDS: environment, dairy, wastewater, physico-chemical properties.

\section{ABSTRACT}

Dairy wastewater consists of transport water and raw materials washing, technology water, condensation water or cooling water from the washing and disinfecting rooms, manufacturing and packaging equipment cleaning and water from plumbing. These wastewaters are characterized by a high turnover of physico-chemical and microbiological properties due to their composition and origin variety. Because of the composition of protein, fat, and lactose, wastewater cannot be discharged to the sewerage system before their purification, because the mere disposal would pollute the environment. The main purpose of this research is to monitorize the quality of water in the milk processors industry, in order to ensure food security by framing it within the limits permitted by current rules.

ZUSAMMENFASSUNG: Untersuchungen zur Qualität des in der Milchindustrie verwendeten Wassers im Kreis Sibiu/Hermannstadt (Transilvanien, Rumänien).

Die Abwässer aus der Milchindustrie entstehen beim Transport, durch Waschen der verwendeten Rohstoffe, als Ergebnis technologischer Prozesse, als Kondens- und Kühlwasser, beim Spülen und der Desinfektion der Produktionsräume, beim Reinigen der Geräte und der Verpackungen sowie aus Rohrleitungen. Diese Abwässer zeichnen sich bedingt durch ihre Zusammensetzung und Herkunft durch eine hohe Fluktuation der physikalisch-chemischen und der mikrobiologischen Eigenschaften aus. Bedingt durch die Zusammensetzung der Proteine, der Fettstoffe und der Laktose können die Abwässer nicht vor einem Reinigunsprozess in die Abwasserrohre geleitet werden, da sie eine Belastung der Umwelt hervorrufen würden. Das Hauptziel der durchgeführten Untersuchungen war ein Monitoring der Wasserqualität in der Milchverarbeitungsindustrie zur Qualitätssicherung im Rahmen der durch die derzeitigen Vorschriften gegebenen Grenzen.

REZUMAT: Cercetări privind calitatea apei folosite în industria laptelui în judeţul Sibiu (Transilvania, România).

Apele reziduale din industria laptelui constau în ape de transport şi spălare a materiei prime, ape tehnologice, ape de condens sau de răcire, ape de la spălarea şi dezinfecţia sălilor de fabricaţie, a utilajelor şi ambalajelor, ape de la instalaţiile sanitare. Aceste ape reziduale se caracterizează printr-o mare fluctuaţie a proprietăţilor fizico-chimice şi microbiologice, datorită varietăţii provenienţei şi compoziţiei acestora. Datorită compoziţiei în proteine, lipide, lactoză, apele reziduale nu pot fi deversate la reţeaua de canalizare înainte să se realizeze epurarea lor, deoarece simpla deversare ar contribui la poluarea mediului înconjurător. Scopul principal al cercetărilor este monitorizarea calităţii apei din industria laptelui, în vederea asigurării securităţii alimentare a acesteia prin încadrarea în limitele conforme normelor. 


\section{INTRODUCTION}

Food wastewater has the characteristics of large high concentration amounts of organic pollutants (Xie and Sun, 2002). One of the main issues is the amount of wastewater continuously produced in the food plants worldwide. Compared to other sectors, the food industry uses a much greater amount of water for each ton of product (Chmiel et al., 1996).

In the future, food and beverage industries will be influenced by the need to comply with EU legislation governing the discharge of industrial effluents (Corporation, 2011). Food industry standards and eco-sanitation concept specify and encourage that processed water intended for reuse - even for cleaning purposes - must be of drinking quality (Mavrov and Bélières, 2000; Elkin et al., 2008; Media, 2012; Curtean-Bănăduc and Bănăduc, 2012; Aquamedia, 2013; Corporation, 2011; Klemeš et al., 2008). Regulations for other applications, such as boiler make-up water or warm cleaning water, are even much more stringent (Media, 2012; Klemeš et al., 2008).

In a background of natural water resource availability and cost increase, wastewater treatment for water reuse can lower the overall water consumption and the global effluent volume of industrial plants (Vourch et al., 2008).

Many older factories were traditionally built near rivers and other natural sources of water, such as springs. Thus, the factory had a supply of water to assist its processing, and also to use as an outlet for the wastewater from the site (Walker, 2008).

Water is used as an ingredient, an initial and intermediate cleaning source, an efficient transportation conveyor of raw materials, and the principal agent used in sanitising plant machinery and areas (Media, 2012). Dairy wastewater is distinguished by the high $\mathrm{BOD}_{5}$ and COD contents, high levels of dissolved or suspended solids including fats, oils and grease, nutrients such as ammonia or minerals and phosphates and therefore requires proper attention before disposal (Sarkar et al., 2006). Milk industry wastewater contains high concentrations of COD, $\mathrm{BOD}_{5}$ and TKN of up to 11,000, 5,900 and $720 \mathrm{mg} / \mathrm{l}$, respectively (Viraraghavan et al., 1994; Sirianuntapiboon et al., 2005). Dairy companies have been using condensate from the evaporation of milk for feeding boilers and for lower grade use after simple treatment with chlorine dioxide (Elkin et al., 2008; Klemeš et al., 2008).

Environmental considerations are receiving an increased priority upon political, social, and economic agendas, especially when related to agriculture (Capper et al., 2009). Disposal of improper treated wastewater often poses risks to the environment (Wu et al., 2005). Using advanced technology to mitigate risk by refined wastewater treatment is a key issue in meeting legislative guidelines, e.g. EU Water Framework Directive (Wu et al., 2005).

Environmental management was regarded as having a function operationally linked and often health and safety at work, while environmental and safety activities include making necessary costs in the business, recognizing that firms implement an environmental management system, have strategic function and help define the entire business strategy, product design, financial and information systems design (Banu and Vizireanu, 1999).

The main purpose of this research is monitoring water quality in the milk processors industry, in order to ensure food security by framing it within the limits permitted by current rules. In order to fulfil this purpose there have been made physico-chemical analyse on wastewater from milk industry units, to ensure optimal quality for their reintegration into the natural circuit. 


\section{MATERIAL AND METHODS}

\section{Research location}

In order to achieve the established goals and objectives, research was conducted at two dairy processing units. To monitor the quality of untreated wastewater samples were collected from the discharge point for wastewater pre-treatment station (for food units that do not have effluent treatment plants - C1) and from the discharge point of the own wastewater treatment stations of food units denoted.

In order to study water quality in the dairy industry, during the 2013-2014 period, wastewater samples were collected (before pre-treatment), from some work control points.

The physico-chemical analysis of water was to determine the organoleptic and physical properties and chemical composition. Water samples were collected in bottles provided with ground glass stoppers.

The main measurements that were made:

- Nitrites were determined by the molecular absorption spectrometric method STAS 12754-89;

- Nitrates were determined by the STAS 12999-91;

- Water hardness was determined by complex metric titration of calcium and magnesium by the method STAS 3026-76;

- $\quad$ pH of water by ISO 10523:2009;

- $\mathrm{BOD}_{5}$ was obtained by determination of oxygen dissolved in water after harvest and after five days by method EN 25814:1999;

- CCO-Cr - Determination of chemical oxygen consumption by method ISO 6060:1996;

- Total suspension was determined by filtration on glass fiber filters by method EN 872:2005;

- Wastewater pH by method ISO 10523:2009;

- Chlorides were analyzed by titration with silver nitrate using chromate as indicator (Mohr method) by method ISO 9297:2001;

- Total nitrogen was determined by method EN 25663:2000;

- Total phosphorus - spectrometric method with Ammonium molybdate ISO 6878:2005.

\section{RESULTS AND DISCUSSION}

After withdrawing the samples from the checkpoints of the monitored units, physicochemical analyses were conducted to determine whether values of water quality indicators are consistent with the maximum limits governed by the regulations in force. The results obtained after realizing all measurements are presented in table 1 .

Knowing the value of biochemical oxygen demand in five days $\left(\mathrm{CBO}_{5}\right)$ is extremely important in assessing wastewater pollution, expressing the amount of biodegradable organic substances contained in that water.

Also determining the chemical oxygen demand $\left(\mathrm{CCO}_{\mathrm{Cr}}\right)$ is extremely important in assessing wastewater pollution, expressing the amount of organic substances in the water subjected to this analysis.

The results obtained show that the pollution degree of the water used is insignificant and therefore this water can be used to collect milk without any influence on the characteristics.

All results obtained show that parameters are compliant to the current legislation in the field. 
Table 1: Monitoring control from the discharge point for wastewater to the pretreatment stations.

\begin{tabular}{|c|c|c|c|c|c|c|c|c|c|c|}
\hline \multirow{2}{*}{$\begin{array}{c}\text { Sample } \\
\text { point }\end{array}$} & \multirow{2}{*}{$\begin{array}{l}\text { Date } \\
\text { Year }\end{array}$} & \multicolumn{2}{|c|}{$\begin{array}{c}15 \\
\text { January }\end{array}$} & \multicolumn{2}{|c|}{$\begin{array}{c}15 \\
\text { March }\end{array}$} & \multicolumn{2}{|c|}{$\begin{array}{c}15 \\
\text { May }\end{array}$} & \multicolumn{2}{|c|}{$\begin{array}{c}15 \\
\text { July }\end{array}$} & \multirow{2}{*}{$\begin{array}{c}\text { Normal } \\
\text { values }\end{array}$} \\
\hline & & C1 & C2 & C1 & C2 & C1 & C2 & C1 & C2 & \\
\hline \multirow{2}{*}{$\begin{array}{l}\mathrm{NO}^{3-} \\
(\mathrm{mg} / \mathrm{l})\end{array}$} & 2013 & 11.52 & 23.12 & 19.14 & 23.36 & 10.65 & 13.78 & 20.02 & 21.34 & \multirow{2}{*}{25.00} \\
\hline & 2014 & 11.52 & 23.12 & 19.14 & 23.36 & 10.65 & 13.78 & 20.02 & 21.34 & \\
\hline \multirow{2}{*}{$\begin{array}{l}\mathrm{NO}^{2-} \\
(\mathrm{mg} / \mathrm{l})\end{array}$} & 2013 & 11.52 & 23.12 & 19.14 & 23.36 & 10.65 & 13.78 & 20.02 & 21.34 & \multirow{2}{*}{2.00} \\
\hline & 2014 & 11.52 & 23.12 & 19.14 & 23.36 & 10.65 & 13.78 & 20.02 & 21.34 & \\
\hline \multirow{2}{*}{$\begin{array}{c}\mathrm{Cl}_{2} \\
(\mathrm{mg} / \mathrm{l})\end{array}$} & 2013 & 11.52 & 23.12 & 19.14 & 23.36 & 10.65 & 13.78 & 20.02 & 21.34 & \multirow{2}{*}{0.50} \\
\hline & 2014 & 11.52 & 23.12 & 19.14 & 23.36 & 10.65 & 13.78 & 20.02 & 21.34 & \\
\hline \multirow[t]{2}{*}{$\mathrm{pH}$} & 2013 & 11.52 & 23.12 & 19.14 & 23.36 & 10.65 & 13.78 & 20.02 & 21.34 & \multirow{2}{*}{ 6.5-8.5 } \\
\hline & 2014 & 11.52 & 23.12 & 19.14 & 23.36 & 10.65 & 13.78 & 20.02 & 21.34 & \\
\hline \multirow{2}{*}{$\begin{array}{c}\mathrm{CBO}_{5} \\
(\mathrm{mg} \\
\left.\mathrm{O}_{2} / \mathrm{l}\right)\end{array}$} & 2013 & 11.52 & 23.12 & 19.14 & 23.36 & 10.65 & 13.78 & 20.02 & 21.34 & \multirow[b]{2}{*}{20} \\
\hline & 2014 & 11.52 & 23.12 & 19.14 & 23.36 & 10.65 & 13.78 & 20.02 & 21.34 & \\
\hline \multirow{2}{*}{$\begin{array}{c}\mathrm{CCO}_{\mathrm{Cr}} \\
(\mathrm{mg} \\
\left.\mathrm{O}_{2} / \mathrm{l}\right)\end{array}$} & 2013 & 11.52 & 23.12 & 19.14 & 23.36 & 10.65 & 13.78 & 20.02 & 21.34 & \multirow[b]{2}{*}{500} \\
\hline & 2014 & 11.52 & 23.12 & 19.14 & 23.36 & 10.65 & 13.78 & 20.02 & 21.34 & \\
\hline \multirow{2}{*}{$\begin{array}{l}\text { Susp. } \\
\text { solids } \\
\text { (mg/l) }\end{array}$} & 2013 & 11.52 & 23.12 & 19.14 & 23.36 & 10.65 & 13.78 & 20.02 & 21.34 & \multirow{2}{*}{35} \\
\hline & 2014 & 11.52 & 23.12 & 19.14 & 23.36 & 10.65 & 13.78 & 20.02 & 21.34 & \\
\hline \multirow{2}{*}{$\begin{array}{l}\text { Total N } \\
(\mathrm{mg} / \mathrm{l})\end{array}$} & 2013 & 11.52 & 23.12 & 19.14 & 23.36 & 10.65 & 13.78 & 20.02 & 21.34 & \multirow{2}{*}{10} \\
\hline & 2014 & 11.52 & 23.12 & 19.14 & 23.36 & 10.65 & 13.78 & 20.02 & 21.34 & \\
\hline \multirow{2}{*}{$\begin{array}{l}\text { Total P } \\
(\mathrm{mg} / \mathrm{l})\end{array}$} & 2013 & 11.52 & 23.12 & 19.14 & 23.36 & 10.65 & 13.78 & 20.02 & 21.34 & \multirow{2}{*}{5} \\
\hline & 2014 & 11.52 & 23.12 & 19.14 & 23.36 & 10.65 & 13.78 & 20.02 & 21.34 & \\
\hline
\end{tabular}

\section{CONCLUSIONS}

Comparative analyses of potable water used in monitored processing units revealed that, although not exceeding the maximum values allowed by current standards, the highest concentrations of nitrites and nitrates as well as the higher water hardness values, are presented at the power units supplied with water from its own source, compared to power units supplied with water from the central source.

Results confirm that the water used to receive raw milk materials has no influence on the milk composition and all the parameters analysed are compliant to the standards imposed by existing legislation. 
ACKNOWLEDGEMENTS

The authors would like to thank the editorial board of this publication. 


\section{REFERENCES}

1. Aquamedia, 2013 - Water Reuse Solutions in Food and Beverage Industry, Online at: http://www.aquamedia.at/templates/index.cfm/id/18562, (accessed 06.06.2013).

2. Banu C. and Vizireanu C., 1999 - Procesarea Industrială a Laptelui, București, Edit. Tehnică, 615-619. (in Romanian)

3. Capper J., Cady R. and Bauman D., 2009 - The environmental impact of dairy production: 1944 compared with 2007, Journal of Animal Science, 87, 2160-2167.

4. Chmiel H., Fähnrich A., Schneider C. and Mavrov V., 1996 - Einsparpotentiale in der Fleischwarenindustrie als Ergebnisse der Umweltprüfung nach der EG-Öko-Audit-Verordnung1, Stoffströme, Fleischwirtschaft, 76, 1019-1023. (in German)

5. Corporation P., 2011 - Quality, cost, legislative concerns push water reuse in Europe's food and beverage industry http://www.waterworld.com/index/display/articledisplay/249219/articles/waterworld/business/q uality-cost-legislative-concerns-push-water-reuse-in-europes-food-beverage-industry.html.

6. Curtean-Bănăduc A. and Bănăduc D., 2012 - Eco-sanitaţia alternativă pentru managementul durabil al nutrienţilor şi resurselor de apă, în Apa resursă fundamentală a dezvoltării durabile. Metode şi tehnici neconvenţionale de epurare şi tratare a apei, I, Oprean L. (ed.), Edit. Academiei Române, 433-437. (in Romanian)

7. $\quad$ Elkin D., Stevens C., Klemeš J., Smith R. and Kim J., 2008 - Environmental and consumer issues regarding water and energy management in food processing, Handbook of water and energy management in food processing, 29-44.

8. Klemeš J., Smith R. and Kim J. K., 2008 - Handbook of water and energy management in food processing, Woodhead Publishing Ltd., ISBN: 978-1-84569-195-0, 1029.

9. Mavrov V. and Bélières E., 2000 - Reduction of water consumption and wastewater quantities in the food industry by water recycling using membrane processes, Desalination, 131, 75-86.

10. Media W. R. B., 2012 - Food production given wake-up call over water scarcity, Online at: http://www.foodproductiondaily.com/Supply-Chain/Food-production-given-wake-up-call-overwater-scarcity, (accessed 04.06.2013).

11. Sarkar B., Chakrabarti P., Vijaykumar A. and Kale V., 2006 - Wastewater treatment in dairy industries - possibility of reuse, Desalination, 195, 141-152.

12. Sirianuntapiboon S., Jeeyachok N. and Larplai R., 2005 - Sequencing batch reactor biofilm system for treatment of milk industry wastewater, Journal of Environmental Management, 76, 177-183.

13. Viraraghavan T., Wise D. and Trantolo D., 1994 - Pollution control in the dairy industry, Process engineering for pollution control and waste minimization, 705-713.

14. Vourch M., Balannec B., Chaufer B. and Dorange G., 2008 - Treatment of dairy industry wastewater by reverse osmosis for water reuse, Desalination, 219, 190-202.

15. Walker S., 2008 - Water Supplies in the Food Industry, Cleaning-in-Place, 32-55.

16. Wu J., Yang Y. and Lin J., 2005 - Advanced tertiary treatment of municipal wastewater using raw and modified diatomite, Journal of Hazardous Materials, 127, 1, 196-203.

17. Xie Ming and Sun Pei-de, 2002 - New Advances in Treatment of Food Wastewater, Pollution Control Technology, College of Food Science, Biotechnology and Environmental Engineering, Hangzhou University of Commerce, Hangzhou, Zhejiang, 310035, China. 